\title{
The Hierarchical Clustering of Tax Burden in the EU27
}

- Simková Nikola

\begin{abstract}
The issue of taxation has become more important due to a significant share of the government revenue. There are several ways of expressing the tax burden of countries. This paper describes the traditional approach as a share of tax revenue to GDP which is applied to the total taxation and the capital taxation as a part of tax systems affecting investment decisions. The implicit tax rate on capital created by Eurostat also offers a possible explanation of the tax burden on capital, so its components are analysed in detail. This study uses one of the econometric methods called the hierarchical clustering. The data on which the clustering is based comprises countries in the EU27 for the period of 1995 - 2012. The aim of this paper is to reveal clusters of countries in the EU27 with similar tax burden or tax changes. The findings suggest that mainly newly acceding countries (2004 and 2007) are in a group of countries with a low tax burden which tried to encourage investors by favourable tax rates. On the other hand, there are mostly countries from the original EU15. Some clusters may be explained by similar historical development, geographic and demographic characteristics.
\end{abstract}

Keywords: bierarchical clustering, implicit tax rate on capital, tax burden, tax system, the EU27

JEL Classification: C38, H21, H29

\section{INTRODUCTION}

Each country has its own tax system, which is based on historical, political, economic, but also on social conditions. Analysing international tax policy and its effects on economic behaviour, market failure and loss of economic efficiency is therefore quite difficult. For this reason were created several ways of expressing the tax burden of countries.

Kirchler (2007) regard the calculation of the tax burden as a complex task. This paper deals with the most common approach as a share of tax revenues to GDP in the country. We can observe the revenue from each type of tax separately. We will focus on the capital taxation because it affects decisions on production activities and thus affects the country's wealth. Moreover, new indicators of taxation have been created. Eurostat constructed the implicit tax rate on capital, which also reflects the level of capital taxation.

The basic research problem is to understand the structure of the tax system and the governments' fiscal policy. Some countries have similar historical development or have similar geographic and demographic characteristics. However, there are cases where countries were very distant, but over time their behaviour began converging. We used the hierarchical clustering to detect different clusters in the EU27. Our goal is through application of this method to reveal clusters of countries with similar tax burden, tax changes, or practices in the field of taxation, for example tax decreasing, increasing or fluctuating around mean, a kind of equilibrium. 
The remaining of the paper is structured as follows. In Section 2, we describe hierarchical clustering and tax system. Section 3 analyses the tax burden in the EU through dendrograms. In Section 4, we focus on the level of capital taxation and present the tax burden on capital together with the implicit tax rate on capital. Finally, Section 5 discusses our results and in the last section some concluding remarks and future lines of research are presented.

\section{HIERARCHICAL CLUSTERING AND TAX SYSTEM}

Hierarchical clustering is of great importance in data analytics especially because of the exponential growth of real-world data (Bouguettaya et al., 2015). It is the econometric method used to organize, compression and data reduction. The result is the cluster, which is well separated from the other cluster through its center point, radius (range), or other characteristics. It depends on the applied metrics - our approach to measuring distance. In practice, the most commonly used is Euclidean distance, but they are also known Manhattan, Chebyshev (maximum), Mahalanobis, Minsky and cosine similarity sentence (Klímek, 2008).

The graphical output of the clustering is the dendrogram representing the nested grouping of patterns and similarity levels at which groupings change (Jain et al., 1999). It reflects superior and inferior levels. Objects in the dendrogram are sorted in order to see as they are gradually linked into clusters. On the horizontal axis are the names of clustering objects and on the vertical axis are plotted the values of clustering levels as the numerical values assigned to each cluster.

According to building the hierarchical structure we distinguish two strategies. The agglomerative (bottom-up) approach brings together clusters at higher levels, taking an overall, minimum, average or ward linkage. The divisive (top-down) strategy divides the large cluster into smaller structures (R-Manual: Hierarchical Clustering).

Among the clustering methods includes the k-means clustering. At the start, we determine the number of clusters (k). Then algorithm divides $n$ observations in these clusters in two steps. Firstly, in the assignment step the dataset is partitioned among the centroids, which characterize the cluster. Secondly, the update step reviews the classification of data in several iterations until the centroids are minimal moved (Klímek, 2008).

The cluster analysis is currently applied in several areas. In marketing the groups of customers with similar characteristics (behaviour) are created on the basis of all customers included in the database. Biology uses the classification of plants and animals based on the identified characteristics. Libraries decided for the formation of book groups. Insurance identifies the insurance groups and fraud. In planning of construction sites, the identification of house groups is based on the type, value, and geographic location. Studies of earthquake create the clusters of the earthquake epicentres to identify hazardous areas. Websites design the classification of documents (Trebuňa \& Beres, 2010).

The different uses of this method inspired us to examine the tax burden in the EU27. Taxes are very important and significant economic and political tools in today's market economy. They also represent one of the key determinants of a country's attractiveness for investments (Budryte, 2005). They can be defined as compulsory monetary payments levied by law specified 
authorities on individuals or companies at specified amount and exactly specified due date to meet the expenditure which is required for public welfare (Šimková, 2011). The basic elements of tax techniques, as defined in the tax law, are the tax subject, tax object, tax base and tax rates. Additional elements of tax techniques may be contained in the tax law and apply depending on the nature of the tax (Lénártová, 2004). Taxes have allocation, redistribution and stabilization functions (Kubátová, 2003).

Countries try to create the optimal tax system that would provide the adequate level of tax revenues and to be bearable for taxpayers (Lisý, et al., 2007). It means how taxes fit together and how the system as a whole achieves government's goals (Kaplow, 2011). States differ in their historical, political and socio-economic development, so there is no general model of the optimal taxation applicable to all countries. Analysing optimal tax policy in numerical studies has a long tradition in the macroeconomic and public finance literature (Fehr \& Kindermann, 2015). Many economists have tried to formulate the basic principles that countries should apply to the tax system to work optimally. In 1776, Smith formulated tax canons (equity, certainty, convenience of payments, and economy of collection). James and Nobes (2003) were inspired by this idea. They determined the tax principles as efficiency, incentive, equity and macroeconomic flexibility. Equity and efficiency are inversely associated. The tax is more equitable when is less effective and vice versa.

Stiglitz (1997) established five requirements that should satisfy the optimal tax system. Administrative simplicity in response to the complexity and lack of transparency of tax systems and legal tax avoidance requires a relatively simple and inexpensive tax system in terms of administration. When laws and regulations are complex, costs and demands on calculation, collection and administration of taxes will rise. Flexibility tax system tells about his ability flexibly responding to changes in the economy. It is influenced by two factors: the reaction of tax rates on new socio-economic conditions may vary, automatically adapt to the built-in stabilizers (for example progressive income tax) and the reaction speed of implementation of tax changes, which in the case of its delays can significantly affect the efficiency and stability of economic growth. Political transparency emphasizes awareness and transparency of taxation, as well as changes in the tax system in legislation and responsibility of governments to their electorate for the amount of taxes and public expenditure. Equity in taxation of different population groups, and there are now two principles of equity assessment. The principle of benefit determines tax liability of the taxpayer based on its benefits, which is a subjective category, although in the case of a specific tax on benefit of goods (for example motorway), which is consumed by only a part of population, may be desirable. The problem may be high administrative costs and tax administration. The principle of solvency defines horizontal fiscal equity (individuals with the same solvency should pay equally, most often based on income and consumption) and vertical tax equity (individuals with higher paying capacity will pay more). We compare the taxpayers with lower income and the higher-income taxpayers. This may be equitable tax system according to the same absolute, proportional, marginal or minimum tax victim as the loss incurred by individuals with regard to payment of taxes. Economic efficiency is based on low cost of collection of the taxes to avoid distorting effects of taxes on the behaviour of taxpayers meaning the inefficient allocation of resources (Medved' \& Nemec et al., 2011). 
Tax revenue is the significant government revenue. In 2012, the annual increase in tax revenue was $3.62 \%$, while total government revenue increased by $3.48 \%$. Taxes represented $85 \%$ of the total government revenue in the EU27. On the graph (Fig. 1) we can see their shares of tax revenue on the total government revenue. Cyprus and Italy had the highest shares (89\%), but in volume won Germany with more than 1000000 million EUR.

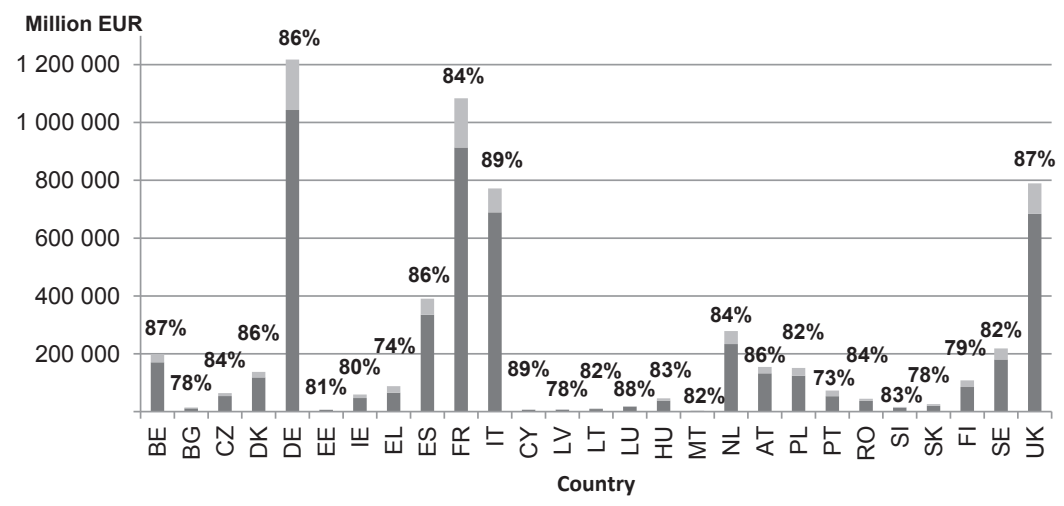

-Tax Revenue $\quad$ Other Revenue $\%$ = Share of Tax Revenue to Total Government Revenue

Fig. 1 - The government revenue in the EU27 in 2012 Source: European Commission (2014a)

On the one hand, it should be realised that taxes are revenue of the state budget, which government wants to maximize. On the other hand, there are interests of the business community and consumers who naturally take taxes as a necessary evil and try to avoid them. They use tax havens, or at least find countries with lower taxation if it is possible (Šimková, 2013). With the increase in tax rates to finance larger public spending programs, the desire to escape taxes and regulatory restrictions also gained in prominence (Tanzi \& Schuknecht, 1997). Tax morale in European countries varies systematically with socio-demographic characteristics, personal financial experiences, political attitudes (Lago-Peñas \& Lago-Peñas, 2010). This contradiction is solved by some form of compromise, although its search is a difficult and long process. Blaufus et al. (2013) found that politicians could simultaneously increase tax revenues and reduce the perceived tax burden for taxpayers. There are also other theories trying to describe it, but the specifics of the development of each country often mean that tax systems applied in different countries are developing different ways corresponding to the particular conditions of the country. Therefore, it is natural that they differ from each other but increased international market integration has affected significantly the design and the scope of fiscal policy (Adam, Kammas \& Lagou, 2013). Through the process of globalisation and internationalisation countries are increasingly interlinked. It is important to reveal clusters of countries with similar tax burden to learn more about these links. 


\section{TAX BURDEN IN THE EU27}

Our analysis of the tax burden through the hierarchical clustering was performed on the EU27 countries for the period 1995-2012. We obtained the dendrograms with the clusters of countries that had similar trends in taxation. We used the traditional approach of expressing the tax burden as a share of tax revenue to GDP (Široký, 2010). Eurostat defines total taxes (incl. SSC) as taxes on production and imports, current taxes on income and wealth, capital taxes, actual compulsory social contributions. Indirect taxes, direct taxes and social contributions add up to the total of taxes received by the general government and the institutions of the European Union.

If we retain the tax burden as the volume of tax revenue to GDP in \% (Fig. 2), it is showed the volume effect and countries are grouped into two main groups. The first branch includes the countries with low tax burden. More than $2 / 3$ of them are newly acceding countries (2004 and 2007), which tried to encourage investors by favourable tax rates. Conversely, on the other hand, there are mostly countries of the original EU15. This group also comprises the welfare states, or countries that provide their inhabitants extensive social benefits. They have to have sufficient funding to finance social policy, through higher tax rates compared to the EU average $(36.5 \%)$. On the dendrogram (Fig. 2), countries with the lowest taxation are labelled in the light box and with the highest in the dark box.

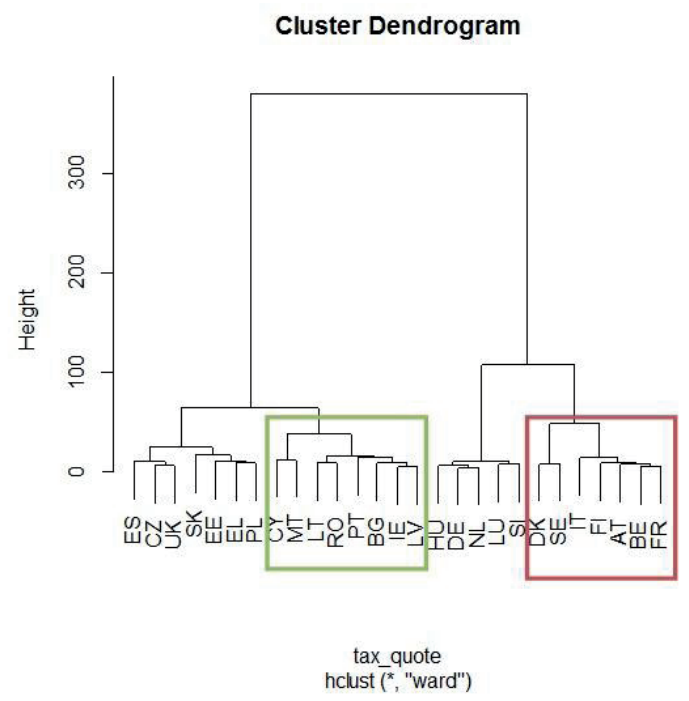

Fig. 2 - The dendrogram based on the tax burden for the EU27 Source: European Commission (2014a)

Thanks to the distribution of the average tax burden during the monitored period we obtained the following groups, which often correspond to the common cluster in a dendrogram (Fig. 2):

1. $<30 \%$ - Romania, the Baltic states Latvia and Lithuania,

2. <30;35) \% - Malta, Ireland, Bulgaria, Portugal, Cyprus, Estonia, Slovakia, Greece, Spain, Poland and Czech Republic,

3. <35;40) \% - United Kingdom, Slovenia, Luxembourg, Hungary, Netherlands and Germany, 
4. $<40 ; 45) \%$ - Italy, Austria, France, Belgium and Finland,

5. $>45 \%$ - the Nordic countries such as Sweden and Denmark.

Although it is necessary to know the tax burden, it is appropriate to ensure comparability of data standardized according to the mean value, which shows the dendrogram (Fig. 3).

\section{Cluster Dendrogram}

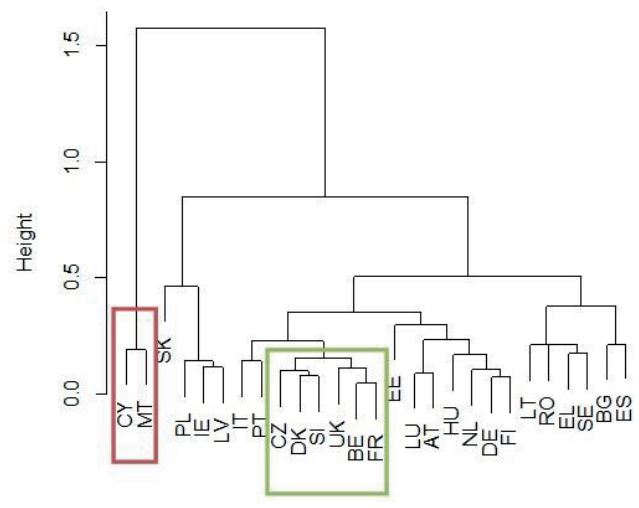

tax_quote_normal

hclust (*, "ward")

Fig. 3 - The dendrogram based on the standardized tax burden for the EU27 Source: European Commission (2014a)

We created the clusters of countries that may be related to the standard deviation, because if we again divided the country according to this indicator, we will acquire the groups that are in the dendrogram (Fig. 3) often viewed as the clusters:

1. $(0.5 ; 1)$ - Slovenia, Belgium, France, United Kingdom, Czech Republic, Denmark and Netherlands,

2. <1;1.5) - Austria, Portugal, Germany, Hungary, Italy, Luxembourg and Romania,

3. <1.5;2) - Finland, Spain, Greece, Latvia, Ireland, Bulgaria, Estonia, Poland and Lithuania,

4. $<2 ; 4)$ - Sweden, Malta and Slovakia,

5. $>4$ - Cyprus as the country with the highest standard deviation.

The value of the standard deviation evaluates how much the tax burden is deviated from the average of the country, but also important is the direction. The cluster in the light box shows us the countries with the lowest standard deviations, where we see two smaller clusters. The countries such as Czech Republic, Denmark and Slovenia reduced the tax burden compared to 1995. Conversely, United Kingdom, Belgium and France increased the tax burden. The cluster in the dark box connects the countries with the high standard deviations, which increased their tax burden compared to 1995 by $8.4 \%$ (Cyprus) and $7.3 \%$ (Malta). 
From the perspective of tax competition is vital to know the change of the tax burden. For this reason we used k-means clustering, which divided the countries into three groups:

1. Bulgaria, Cyprus and Hungary with the sum of squares 42.7 .

2. Estonia, Italy, Lithuania, Malta, Austria and Luxembourg with the sum of squares 94.4.

3. Other countries EU27 with the sum of squares 204.3.

The share of the sum of squares of clusters to the total amount of squares is $29.5 \%$. The output of the k-means refers to the creation of three main groups of countries - the countries with the greatest changes in the tax burden (1), the countries with a slight modification (2) and the other EU countries, where the tax burden fluctuated around equilibrium. The most volatile countries during the monitored period were Bulgaria, Cyprus and Hungary.

The total tax burden in the EU27 decreased in 2012 compared to 1995 by only $0.4 \%$ to $36.3 \%$ of GDP. The lowest value (35.6\%) was achieved in 2009 as a result of loss of tax revenue due to the crisis.

If we look at the structure of taxes by the type of the tax base, we divide taxes on consumption, labour and capital. On the graph (Fig. 4) we see their share to the total tax. The largest share was represented by taxes on labour (average $47.1 \%$ ). Consumption during the monitored period had volatile development. Capital was in 2012 on the level (18.6 \%), which was almost identical to 1995. The largest share was recorded in 2007 , before the outbreak of the crisis in the EU.

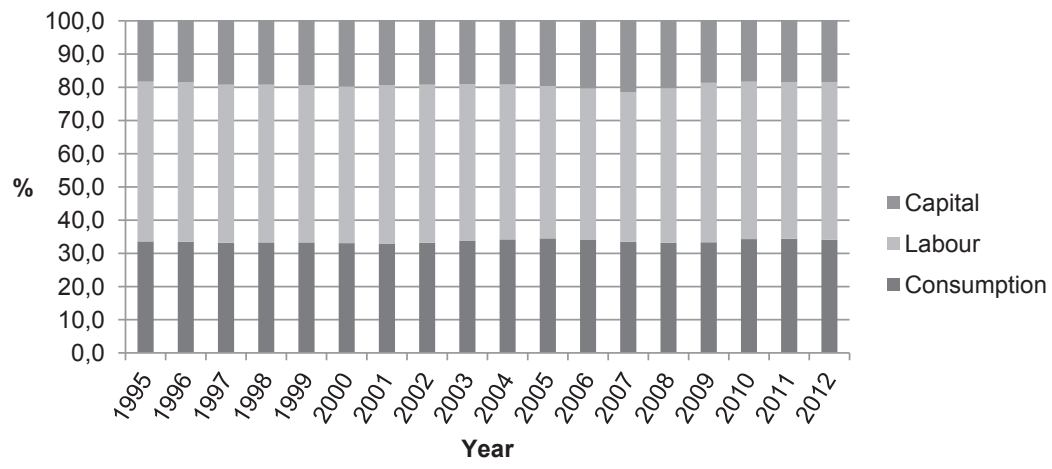

Fig. 4 - The types of taxes as \% of the total taxation in the EU27 Source: European Commission (2014a)

When we analyse the structure of the tax system dividing the tax burden on consumption, labour and capital, we can group EU27 countries into the following clusters that are showed in the dendrogram (Fig. 5). We used the average tax burden for the time series 1995-2012 for the type of taxes and the country in the clustering. 


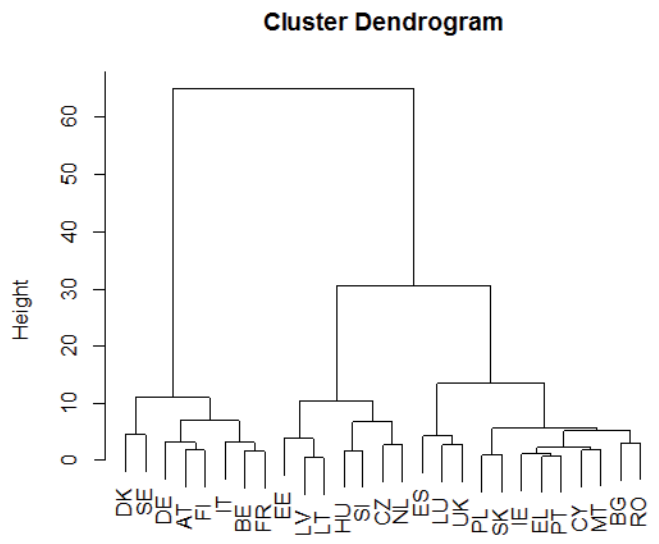

$$
\begin{gathered}
\text { tax_structure } \\
\text { hclust (* , "ward") }
\end{gathered}
$$

Fig. 5 - The dendrogram based on the average tax burden on consumption, labour and capital for the EU27 Source: European Commission (2014a)

From these clusters, we can see how countries clustered according to similarities in consumption, labour and capital taxation. A lot of clusters can be also explained in terms of geography. Countries were close in the past, for example, had a similar historical development, or due to the proximity can easily compete, thereby is gradual reducing differences among prices, wages, and of course also taxes. There are the Baltic countries Lithuania - Latvia - Estonia, Poland - Slovakia, Hungary - Slovenia, Belgium - France - Italy, Denmark - Sweden, Bulgaria - Romania. There is interesting also the cluster of Ireland - Greece - Portugal - Cyprus - Malta, where countries are not neighbours, but there are countries that separate Europe from the sea, so they may be similar in the structure of the tax system.

\section{LEVEL OF CAPITAL TAXATION IN THE EU-27}

Our focus is on the taxation of capital, which is widely held to be the most mobile factor (Griffith, Hines \& Sorensen, 2010). Capital is the driving force of the economy and consists of physical capital, intangibles, financial investments and savings. Tax policy fundamentally affects a large part of the strategic, operational and decision-making processes of the company (Solík, 2007). Capital taxes include taxes on business income, not only in the form of taxes on profits, but also taxes that could be regarded as a prerequisite for entering into earning profit, such as the real estate tax and motor vehicle tax paid by enterprises (Taxation trends in the European Union: Methodology, 2014). The empirical study confirmed that these indirect taxes affect investment decisions of US multinational companies. They also include taxes on capital stock of household or transactions (Desai, Foley \& Hines, 2002).

The basic approach for expression of the tax burden on capital in the economy is considered the volume of revenue from capital taxes in relation to GDP. This indicator is obtained relatively 
quickly due to easy availability of the required input data. However, the interpretation is questionable, it would be useful to know reasons for this value. If the tax burden on capital rises in value, it could be due to increasing the tax rate on capital, broadening the tax base or falling in GDP. Especially during the recession, even with unchanged parameters of the tax system may reflect the influence of the last-mentioned factor, which may indicate that, it is appreciable higher taxation regards to the current performance of economy.

Among the EU member states, we can discover the clusters, where there is the common similar development of the tax burden on capital. On the dendrogram (Fig. 6) we see the overview for the period 1995-2012.

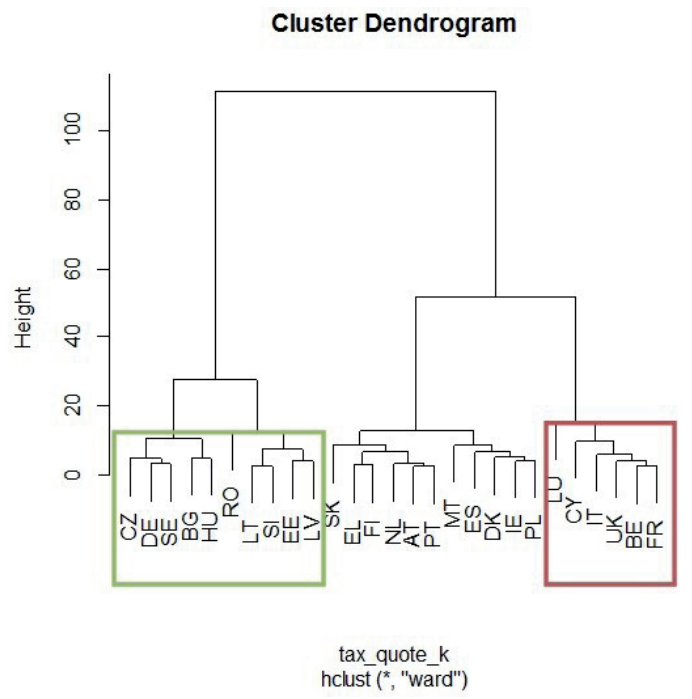

Fig. 6 - The dendrogram based on the tax burden on capital for the EU27 Source: European Commission (2014a)

The countries are labelled according to the average value during the monitored period while dark symbolises the highest values (over $9 \%$ ) and the lowest are light (to $6.3 \%$ ). Luxembourg has kept the leadership as the country with the highest tax burden on capital (average $12.0 \%$ ), with the exception of 2007 when Cyprus achieved 14.0\%. In the case of the lowest value, Estonia, Latvia, Lithuania and Slovenia in the particular year varied, but on average Estonia achieved the minimum at the level of $2.6 \%$. For these reasons, it is evident different share of tax revenues to GDP. There was the smallest fluctuation from the mean value in the case of Belgium, Portugal and Estonia. The largest increase was recorded in Malta by $3.4 \%$. Slovakia had the highest decrease in the tax burden on capital (by $4.8 \%$ ).

Within the tax burden on capital, we can see the components of taxes on capital on the graph (Fig. 7). 


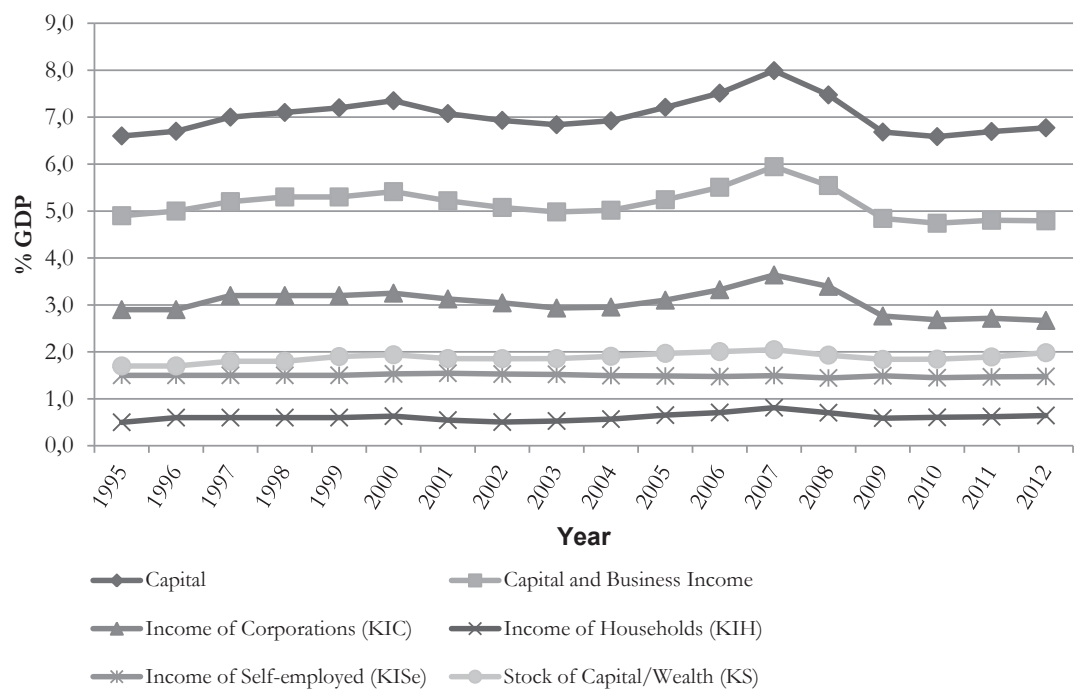

Fig. 7 - The components of the tax burden on capital in the EU Source: European Commission (2014a)

As it can be seen from the graph (Fig. 7), the tax burden on capital in the EU was the highest (8 $\%$ of GDP) in 2007 . The methodology of Eurostat understands total capital as the sum of capital and business income and capital stock / wealth (KS). The first item had the similar trend as the total burden of capital. In 2012, it achieved the same level as in 1995. The highest value $8 \%$ of GDP) belonged to Luxembourg. Conversely, Estonia achieved permanently the lowest values - it was $1.7 \%$ of GDP in 2012. The second item increased during the monitored period in the EU by $0.3 \%$ to $2.0 \%$ of GDP. The values of the countries like France, United Kingdom and Belgium were more than twice over the EU average. Estonia and Lithuania reached the lowest value among the EU27 countries (0.6\% of GDP).

Capital and business income can be divided more detailed into income of companies (KIC), income of households (KIH) and income of self-employed (KISe). KIC recorded in 2012 a decrease by $0.9 \%$ compared to 2007 , when it reached the maximum of $3.6 \%$ of GDP. Malta as the country with the highest value (6.3\% of GDP) in 2012 increased the level of this indicator by $3.7 \%$ compared to 1995. In Greece, after reaching the maximum value in 2000 ( $4.1 \%$ of GDP), there was a downward trend and the value was 1.1\% of GDP in 2012.

KIH achieved relatively low values ( $0.6 \%$ of GDP). The highest value ( $2.2 \%$ of GDP) was attributed to Denmark in 2012, which during the monitored period showed a loss of this type of tax, while Netherlands it reached permanently (-1.0\% of GDP). The average value of KISe in EU27 was $1.5 \%$ of GDP. Self-employed were the most burdened by taxes in Poland $(3.6 \%$ of GDP) and Italy (3.1\%). Latvia taxed them the lowest in 2012 (0.1\% of GDP).

The size of the tax revenue is affected by several factors. Probably the most important is the tax rate. In the case of Corporate Income Tax (CIT), the mean value in the EU27 in 1995 decreased from $35.3 \%$ to the value of $23.5 \%$ in 2012 . Because of the crisis some countries in the EU had to adopt stabilization measures, which led to the small increase tax revenue. 
Expression of the tax burden as a share of tax revenue to GDP is not very suitable for comparison of the tax systems because it does not include the size of the tax base and other aspects. For this reason, different indicators have been created to assess the size of the tax burden on capital such as ITR.

Eurostat modernized assessment of the tax burden through the implicit tax rates. ITR on capital is calculated as a share of revenue from all capital taxes, and all potentially taxable capital and business income in the economy (European Commission, 2014b). They can be understood as taxes levied on the income that was earned by savings and investment of firms and households, possibly related to the stock of capital that is a result of savings and investment in the previous periods. ITR on capital includes net operating surplus, imputed rents, net mixed income, interest, insurance property income, rents on land and dividends for the non-financial and financial corporations, households, self-employed, non-profit organizations, general government and the rest of the world. The aim is to establish the average tax burden imposed on capital income.

The graph (Fig. 8) shows the development of the ITR on capital in the EU. The lack of data for countries Bulgaria, Greece, Luxembourg, Malta, Romania and Germany means that the monitored period is only from 2000. The development of ITR on capital copies the tax burden on the graph (Fig. 7) and the maximum was $27.0 \%$ in 2007. From this peak, the value decreased to $23.5 \%$ in 2012. France has increased during the monitored period its value by $6.6 \%$ to $46.9 \%$, which puts it in the first place. The Baltic countries (Estonia, Latvia and Lithuania) reached values below $10 \%$. Also thanks to this feature they are located in the common cluster in the dendrogram (Fig. 5).

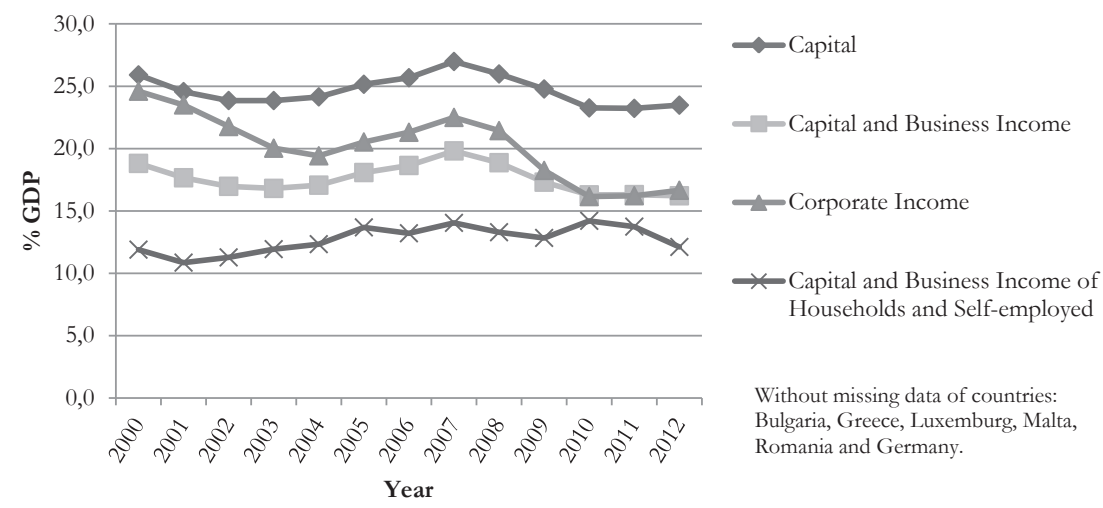

Fig. 8 - The components of the implicit tax rate on capital in the EU Source: European Commission (2014a)

On the graph (Fig. 8) it can be seen the development of the components of ITR. ITR from Capital and Business Income reached the highest rates in Italy $(26.5 \%)$ and France $(25.7 \%)$. Conversely, the lowest value (5.8 \%) in 2012 was reached in Latvia, where its maximum (14.0\%) was reached in 2008. After this year, it was a downward trend.

An interesting situation occurs with the Corporate Income. After the crisis, it fell to the level of Capital and Business Income. Of course, the crisis affected mainly corporate activity and earn- 
ings. Thanks to this indicator, it is also possible to see the diversity of the EU. On the one hand, Cyprus and France had higher values than $28 \%$, on the other hand, Lithuania had only $4.1 \%$.

Only ITR of Capital and Business Income of Households and Self-employed increased compared to 2000 . Among the trio of countries with the highest ITR of this component included France (19.7 \%), Ireland and Italy (18.6 \%). The lowest value in 2012 achieved Latvia (3.0 \%).

ITR on capital is sensitive to the business cycle, but this effect disappears over time to compensate for capital gains with losses. The negative impact on tax revenues may have a strong reduction in the statutory corporate income tax rates, but this may be offset by broadening the tax base. Also, harmful tax competition can take the capital from the country.

\section{DISCUSSION}

This research was intended to reveal clusters of countries in the EU27 with similar tax burden or tax changes. For our analysis, we used the traditional approach of expressing the tax burden as a share of tax revenue to GDP. This indicator is easy available, but unfortunately we cannot identify whether its increase is caused by increasing the tax rate, broadening the tax base or falling in GDP. According to OECD (2010), tax base-broadening reforms are identified as growthoriented reforms while higher rates may create additional efficiency losses. The final decision on how to raise tax revenue is, of course, a political one.

In our paper, we analysed the tax burden on capital also through ITR on capital, but there is a problem with missing data. Future clustering analysis with other indicators of measuring the tax burden should be useful. Haverals (2007) claims that effective rates are specifically designed to assess tax burdens as well as the impact of taxes on the economic activity. It should be interesting to find also this aspect in clusters. For example, alternative measures of corporate tax rates are effective marginal and average rates (Plesko, 2003).

We think further research would include also the development of public deficits and budget with national approaches to their solution and other aspects linked to the level of taxation and tax burden. Wang (2007) used also cluster analyses to examine the convergence property of the tax burden and per capita GDP among Taiwan, China and the OECD countries in the 1970s, 1980s and 1990s. His results showed that there was no significant relationship between the integration process and fiscal convergence among countries, but the convergence of tax burden was found in the group of China, Taiwan and Korea. Therefore, it is important to investigate also the situation outside the EU.

\section{CONCLUSION}

It is important to understand the development and the current status of capital taxation. This analysis has concentrated on this area. For identifying the clusters of countries with similar tax burden we used the hierarchical clustering analysis. We found that the highest total tax burden was reached in the Nordic countries (Denmark, Sweden and Finland). On the other hand, there were the countries such as Romania, Latvia and Lithuania, where residents paid the lowest taxes. The most volatile countries were Bulgaria, Cyprus and Hungary. The total tax burden in the 
EU27 in 2012 compared to 1995 decreased by only $0.4 \%$ to $36.3 \%$ of GDP. The lowest value $(35.6 \%)$ was achieved in 2009 as a result of loss of tax revenue due to the crisis.

Capital is the driving force of the economy and the main motive of tax competition, so it is useful to focus on the tax burden on capital. The findings of our study show that countries such as Luxembourg, Italy and the United Kingdom achieved the highest values. Estonia, Latvia and Lithuania had the lowest capital taxation. The highest growth (by $3.4 \%$ ) was recorded in Malta, the largest decline in Slovakia (almost by $5 \%$ ). This method is not very suitable for comparison of tax systems because it not includes the size of the tax base and other aspects.

For this reason, different indicators have been created. They assess the size of the tax burden on capital. Eurostat introduced the implicit tax rate on capital, in which the level of corporate taxation is complicated to determine and depends on the method of data collection. The lack of data needed for calculation ITR on capital means that we cannot compare all countries in the EU27. In 2012, the value of ITR on capital in the EU was at $23.5 \%$, which represents a decrease of 3.5 $\%$ from the peak in 2007. France has increased during the monitored period its value by $6.6 \%$ to $46.9 \%$, which puts it in the first place. The Baltic countries (Estonia, Latvia and Lithuania) reached values below $10 \%$. Our analysis offers suggestive evidence that ITR on capital gives similar results compared to the tax burden on capital calculated as volume of revenue from capital taxes in relation to GDP because it is based on the real results achieved in the past.

We think possible areas for further research include clustering analysis with other indicators of measuring the tax burden, such as effective tax rates, the development of public deficits and budget and other aspects linked to the level of taxation and tax burden. Moreover, investigate also the situation outside the EU.

\section{References}

1. Adam, A., Kammas, P., \& Lagou, A. (2013). The effect of globalization on capital taxation: What have we learned after 20years of empirical studies? Journal of Macroeconomics, 35(1), 199-209. http://doi.org/10.1016/j.jmacro.2012.09.003

2. Blaufus, K., Bob, J., Hundsdoerfer, J., Kiesewetter, D., \& Weimann, J. (2013). Decision heuristics and tax perception - An analysis of a tax-cut-cum-base-broadening policy. Journal of Economic Psychology, 35, 1-16. http://doi.org/10.1016/j.joep.2012.12.004.

3. Bouguettaya, A., Yu, Q., Liu, X., Zhou, X., \& Song, A. (2015). Efficient agglomerative hierarchical clustering. Expert Systems with Applications, 42(5), 2785-2797. http://doi. org/10.1016/j.eswa.2014.09.054.

4. Budryte, A. (2005). Corporate income taxation in Lithuania in the context of the EU. Research in International Business and Finance, 19(2 SPEC. ISS.), 200-228. http://doi. org/10.1016/j.ribaf.2004.12.002.

5. Desai, M., Foley, C., \& Hines, J. (2002). Chains of Ownership, Regional Tax Competition, and Foreign Direct Investment. Retrieved from http://wcfia.harvard.edu/files/wcfia/files/578_ chains_of_ownership.pdf.

6. European Commission. (2014a). Taxation trends in the European Union: Main results (2014 ed.). Luxembourg: Office for Official Publications of the European Communities. Retrieved 
from http://ec.europa.eu/taxation_customs/resources/documents/taxation/gen_info/ economic_analysis/tax_structures/2014/report.pdf.

7. European Commission. (2014b). Taxation trends in the European Union: Methodology (2014 ed.). Luxembourg: Office for Official Publications of the European Communities. Retrieved from http://ec.europa.eu/taxation_customs/resources/documents/taxation/gen_info/ economic_analysis/tax_structures/2014/methodology.pdf.

8. Fehr, H., \& Kindermann, F. (2015). Taxing capital along the transition - Not a bad idea after all? Journal of Economic Dynamics and Control, 51, 64-77. http://doi.org/10.1016/ j.jedc.2014.09.024.

9. Griffith R., Hines, J., \& Sorensen, P. B. (2010). International Capital Taxation. Dimensions of Tax Design: the Mirrlees Review. Retrieved from http://www.ifs.org.uk/uploads/ mirrleesreview/dimensions/ch10.pdf.

10. Haverals, J. (2007). IAS/IFRS in Belgium: Quantitative analysis of the impact on the tax burden of companies. Journal of International Accounting, Auditing and Taxation, 16(1), 69-89. http://doi.org/10.1016/j.intaccaudtax.2007.01.005.

11. Jain, A. K., Murty, M. N., \& Flynn, P. J. (1999). Data clustering: A review. ACM Computing Surveys, 31(3), 264-323. doi:10.1145/331499.331504

12. James, S., \& Nobes, Ch. (2008). The Economics of Taxation. London: Fiscal Publications.

13. Kaplow, L. (2011). An Optimal Tax System*. Fiscal Studies, 32(3), 415-435. doi:10.1111/ j.1475-5890.2011.00144.x.

14. Kirchler, E. (2007). The economic psychology of tax behaviour. Cambridge: Cambridge University Press.

15. Klímek, P. (2008). Shlukovací metody v Data Miningu. Ekonomie a manažment, no. 2/XI. Retrieved from http://www.ekonomie-management.cz/download/1331826675_2e7a/11_ klimek.pdf.

16. Kubátová, K. (2003). Daňová teorie a politika. Praha: ASPI.

17. Lago-Peñas, I., \&Lago-Peñas, S. (2010). The determinants of tax morale in comparative perspective: Evidence from European countries. European Journal of Political Economy, 26(4), 441-453. http://doi.org/10.1016/j.ejpoleco.2010.06.003.

18. Lénártová, G. (2004). Daňové systémy. Bratislava: Vydavatel’stvo Ekonóm.

19. Lisý, J. et al. (2007). Ekonómia v novej ekonomike. Banská Bystrica: Iura Edition.

20. Medved', J., Nemec, J. et al. (2011). Verejné financie. Bratislava: Sprint dva.

21. OECD (2010). Choosing a broad base - low rate approach to taxation. OECD Tax Policy Studies, No. 19, OECD Publishing. Retrieved from http://www.oecd.org/ctp/taxpolicy/46605624.pdf.

22. Plesko, G. a. (2003). An evaluation of alternative measures of corporate tax rates. Journal of Accounting and Economics, 35(2), 201-226. http://doi.org/10.1016/S0165-4101(03)00019-3.

23. R-Manual: Hierarchical Clustering. Retrieved from http://stat.ethz.ch/R-manual/R-patched/ library/stats/html/hclust.html. 
24. Šimková, N. (2011). Harmonizácia priamych daní v EÚ. Košice: TUKE, EkF.

25. Šimková, N. (2013). Efektivna priemerná dañová sadæ̧ba z kapitálu v krajinach EÚ a V4 študovaná metódami z̧blukovej analýzy. Košice: TUKE, EkF.

26. Široký, J. (2010). Dane v Evropské unii. Praha: LINDE.

27. Smith, A. (2008). Wealth of Nations. London: Oxford University Press.

28. Solík, J. (2007). Súcasný stav a tendencie vývoja harmonizácie daní v Európskej únii. Daňová konkurencia áno či nie? Bratislava: Nadácia F.A.Hayeka.

29. Stiglitz, J. E. (1997). Ekonomika veřejního sektoru. Praha: Grada Publishing.

30. Tanzi, V., \& Schuknecht, L. (1997). Reconsidering the fiscal role of government: the international perspective. American Economic Review, 87, 164-168.

31. Trebuňa, P., \& Beres, M. (2010). Klasifikácia metód zhlukovania a oblasti ich využitia. Transfer inovácií, no 16. Retrieved from http://www.sjf.tuke.sk/transferinovacii/pages/ archiv/transfer/16-2010/pdf/31-34.pdf.

32. Wang, D. H. M. (2007). Convergence tests on tax burden and economic growth among China, Taiwan and the OECD countries. Physica A: Statistical Mechanics and Its Applications, 380(1-2), 278-286. http://doi.org/10.1016/j.physa.2007.02.046.

\section{Contact information}

Ing. Nikola Simková

Technical University of Košice, Faculty of Economics

Nemcovej 32, 04001 Kosice

Tel.: 00421556023202

E-mail:nikola.simkova@tuke.sk. 